\section{PERLINDUNGAN HUKUM TERHADAP PEKERJA OUTSOURCING ${ }^{1}$ \\ Oleh: Nicky E.B Lumingas ${ }^{2}$}

\section{ABSTRAK}

Outsourcing atau alih daya merupakan penyerahan pekerjaan tertentu suatu perusahaan kepada pihak lain yang dilakukan dengan tujuan untuk membagi resiko dan mengurangi beban perusahaan tersebut. Usaha bisnis seperti ini sebenarnya usaha yang saling menguntungkan para pihak, baik pada perusahaan pemberi pemborongan pekerjaan dengan perusahaan penerima pemborongan pekerjaan serta pekerja/buruh didalamnya. Karena semua mengenai outsourcing baik perusahaan outsourcing dan pekerja outsourcing sudah diatur dalam Undang-Undang Nomor 13 Tahun 2003 tentang Ketenagakerjaan. Namun sangat disayangkan karena kurangnya pengetahuan hukum dari pekerja/buruh dan kurangnya pengawasan dari pemerintah sehingga seringkali hakhak dari pekerja/buruh dirampas oleh perusahaan-perusahaan yang nakal. Diperlukan perlindungan hukum dari pemerintah berupa pengawasan dan tindakan yang tegas kepada perusahaanperusahaan yang merampas hak-hak dari pekerja/buruh. Hal seperti ini guna untuk memberikan rasa aman dan nyaman bagi pekerja/buruh dalam melaksanakan tugas tanggung jawabnya, baik di pekerjaan maupun dalam keluarga pekerja/buruh. Sehingga terjalin hubungan yang harmonis antara pekerja/buruh, perusahaan penerima pemborongan atau perusahaan penyedia jasa pekerja/buruh dengan perusahaan pemberi pemborongan pekerjaan.

Kata Kunci : Outsourcing

\section{PENDAHULUAN}

\section{A. Latar Belakang}

Perkembangan dunia usaha di Indonesia yang semakin bertumbuh banyak dan berdaya saing yang ketat, membuat pemilik perusahaan-perusahaan untuk berusaha meningkatkan kualitas kinerja usahanya yang efektif dan efisien dengan mempekerjakan pekerja/buruh semaksimal mungkin dengan jumlah tenaga kerja seminimal mungkin dengan harapan pekerja/buruh dapat memberikan kontribusi dan keuntungan yang besar bagi perusahaan sesuai dengan sasaran perusahaan tempat mereka bekerja. Salah satu cara yang berkembang saat ini yang banyak dilakukan oleh pengusaha yaitu fokus menangani pekerjaan yang menjadi bisnis inti (core business), sedangkan pekerjaan penunjang bagi perusahaan di serahkan kepada pihak lain melalui perusahaan penyedia jasa. Proses kegiatan inilah yang dikenal dengan istilah outsourcing. Dasar dari outsourcing yaitu Pasal 64 Undang-Undang Republik Indonesia Nomor 13 Tahun 2003 tentang Ketenagakerjaan, yang berbunyi perusahaan dapat menyerahkan sebagian pelaksanaan pekerjaan kepada perusahaan lainnya melalui perjanjian pemborongan pekerjaan atau penyediaan jasa pekerja/buruh yang dibuat secara tertulis. Dalam perkembangannya sistem ini sangat membantu perusahaan dalam meningkatkan kegiatan-kegiatan produksinya, Gagasan awal berkembangnya outsourcing sebenarnya adalah untuk membagi resiko usaha dalam berbagai masalah dan belum di identifikasi sebagai strategi bisnis. $^{3}$

Outsourcing sebenarnya adalah sistem yang sudah diterima secara global di negara-negara lain, akan tetapi disebabkan kurangnya pengawasan pemerintah

\footnotetext{
${ }^{3}$ Sehat Damanik, 2006, outsourcing dan perjanjian kerja, DSS Publishings, Hal 2
} 
membuat banyak perusahaan menerapkan sistem outsourcing melenceng dari aturan semestinya, outsourcing dipakai perusahaan sebagai jalan keluar untuk mengurangi upah buruh, sehingga mengarah ke perbudakan modern. ${ }^{4}$ Dalam memulai hubungan kerja antara pekerja outsourcing dengan perusahaan haruslah membuat suatu perjanjian kerja guna mengetahui kejelasan status dari pekerjaannya, hal seperti ini sangatlah bermanfaat bagi pekerja outsourcing agar untuk mengetahui hak dan kewajiban pekerjaannya. Keberadaan hukum ketenagakerjaan sangat strategis dan mendasar, hal ini terjadi karena muatan nya bukan hanya teknis semata, tetapi juga penuh dengan muatan sosial, ekonomi, dan politik yang juga berkaitan dengan masalah hak asasi manusia. ${ }^{5}$ Dalam kenyataannya ada beberapa kalangan pekerja dan pengusaha masih berbeda pandangan terhadap putusan Mahkamah Konstitusi ini sehingga masalah outsourcing masih merupakan masalah yang perlu diselesaikan oleh pemerintah. Adapun usaha yang dilakukan serikat pekerja/buruh untuk mendapat perlindungan dan haknya yaitu melakukan demonstrasi besarbesaran di berbagai daerah serta melakukan pemberitaan-pemberitaan di media cetak dan elektronik yang pada intinya serikat pekerja/buruh menuntut pemerintah untuk memperhatikan nasib mereka dan juga menuntut kepada pemerintah agar menghentikan sistem outsourcing, dikarenakan sistem seperti ini hanya untuk merugikan pekerja dalam jenjang karir mereka karena tidak ada peningkatan jabatan dalam kerja dengan

\footnotetext{
${ }^{4}$ Leila Nagib, dikutip dari http:///www.tempo.com, sistem outsourcing melenceng dari tujuan, di Buat Pada Tanggal 24 April 2012, di Unduh Pada Tanggal 14 Januari 2013.

5 Bahder Johan Nasution, 2004, Hukum Ketenagakerjaan Kebebasan Berserikat bagi Pekerja, Bandung: Penerbit Mandar Maju, Hal 4.
}

kata lain mereka akan menjadi budak selama mereka bekerja di perusahaan.

Adapun masalah pekerja outsourcing yang di muat dalam salah satu media cetak di Manado, diketahui dalam pemberitaan tersebut bahwa ada beberapa hak pekerja outsourcing yang belum di realisasikan perusahaannya seperti jaminan kesehatan yang sampai berita tersebut di muat belum juga terealisasikan dan juga di jelaskan oleh salah satu pekerja outsourcing bahwa gaji/upahnya berkurang ketika mereka tidak masuk kerja karena sakit meski sudah menyertakan surat sakit dari dokter. ${ }^{6}$ Juga masalah lainnya yang biasa terjadi yaitu ketika ada perusahaan yang terkena masalah yang mengharuskan perusahaan tersebut untuk melakukan pemutusan hubungan kerja (PHK) biasanya yang menjadi korban untuk di PHK terlebih dahulu yaitu pekerja outsourcing oleh karena itu hal-hal seperti demikian pastinya bukan untuk melindungi pekerja outsourcing akan tetapi hanya membuat para pekerja merasa tidak nyaman dalam bekerja karena tidak ada kepastian hukum untuk melindungi mereka.

Sehingga pada tanggal 21 Maret 2011, melalui Putusan Mahkamah Konstitusi No. 27/PUU-IX/2011 yang menguji UndangUndang Nomor 13 Tahun 2003 tentang Ketenagakerjaan Pasal 59, Pasal 64, Pasal 65 dan Pasal 66. Dan pada tanggal 5 Januari 2012 Mahkamah Konstitusi telah diputuskan permohonan peninjauan Undang-Undang Ketenagakerjaan yang diajukan oleh Ketua Umum Aliansi Petugas Pembaca Meteran Listrik dimana lewat putusan Mahkamah Konstitusi mensyaratkan bahwa perjanjian kerja waktu tertentu" dalam Pasal 65 ayat (7) dan frasa "...perjanjian kerja untuk waktu tertentu" dalam Pasal 66 ayat (2) huruf b

\footnotetext{
6 Vide Koran Tribun Manado, No 350/Tahun IV, 25 Januari 2013, Penerbit PT. Manado Media Grafika, hal. 9.
} 
Undang-Undang Nomor 13 Tahun 2003 tentang Ketenagakerjaan (Lembaran Negara Republik Indonesia Tahun 2003 Nomor 39, Tambahan Lembaran Negara Republik Indonesia Nomor 4279) bertentangan dengan Undang-Undang Dasar Negara Republik Indonesia Tahun 1945 sepanjang dalam perjanjian kerja tersebut tidak disyaratkan adanya pengalihan perlindungan hak-hak bagi pekerja/buruh yang objek kerjanya tetap ada, walaupun terjadi pergantian perusahaan yang melaksanakan sebagian pekerjaan borongan dari perusahaan lain atau perusahaan penyedia jasa pekerja/buruh. ${ }^{7}$ Menurut Aliansi Petugas Pembaca Meter Indonesia mengatakan bahwa outsourcing yang diatur dalam Undang-Undang Nomor 13 Tahun 2003 tentang Ketenagakerjaan bertentangan dengan Undang-Undang Dasar Republik Indonesia 1945 yang menjamin mengenai hak atas pekerjaan dan penghidupan yang layak bagi kemanusiaan, hak untuk bekerja serta mendapat imbalan dan perlakuan yang adil dan layak dalam hubungan kerja.

\section{B. Permasalahan}

1. Bagaimana perlindungan hukum terhadap pekerja outsourcing berdasarkan Undang-Undang Nomor 13 Tahun 2003 tentang Ketenagakerjaan?

2. Bagaimana implementasi perlindungan pekerja outsourcing pasca putusan Mahkamah Konstitusi Nomor 27/PUUIX/2011?

\section{Metode Penelitian}

Untuk dapat menjawab rumusan masalah yang telah dijabarkan di atas, maka dalam kesempatan ini penulis menggunakan metode penelitian hukum normatif, yaitu bahan-bahan yang

\footnotetext{
7 Vide Putusan MK No. 27/PUU-IX/2011 Perihal Pengujian Undang-Undang Nomor 13 tahun 2003 tentang ketenagakerjaan Terhadap Undang-Undang Dasar Negara Rebuplik Indonesia 1945.
}

dikumpulkan dengan melakukan studi kepustakaan yang terdiri dari:

1. Bahan hukum primer, yaitu peraturan perundang-undangan nasional.

2. Bahan hukum sekunder, yaitu literatur, karya ilmiah, majalah, internet.

3. Bahan hukum tersier, yaitu kamus, kamus hukum, ensklipedi.

\section{PEMBAHASAN}

\section{A. Perlindungan Hukum Terhadap Pekerja Outsourcing Berdasarkan Undang-Undang Nomor 13 Tahun 2003 tentang Ketenagakerjaan.}

Outsourcing merupakan bisnis kemitraan dengan tujuan memperoleh keuntungan bersama, ${ }^{8}$ salah satu bentuk pelaksanaan outsourcing adalah melalui perjanjian pemborongan pekerjaan. $^{9}$ Dalam menjalankan kegiatannya, perusahaan pemborong memiliki hubungan kerja dengan pekerja, sedangkan hubungan antara perusahaan pengguna dan perusahaan pemborong hanyalah terkait dengan pekerjaan yang diborongkan tersebut. ${ }^{10}$ Secara garis besar terdapat dua jenis karyawan, yakni karyawan kontrak dan tetap. Karyawan kontrak didasarkan pada Pasal 59 Undang-Undang Nomor 13 Tahun 2003 tentang Ketenagakerjaan dan Keputusan Menteri Tenaga Kerja dan Transmigrasi KEP. 100/Men/VI/2004 tentang Ketentuan Pelaksanaan Pekerjaan Waktu Tertentu (PKWT). ${ }^{11}$ Hubungan kerja yang terbentuk dalam penyerahan sebagian pelaksanaan pekerjaan kepada perusahaan (outsourcing) berdasarkan UU No. 13 Tahun 2003, baik melalui pemborongan kerja maupun penyedia jasa pekerja/buruh adalah tetap berdasarkan perjanjian kerja secara tertulis antara perusahaan pemborong pekerjaan atau perusahaan penyedia jasa pekerja/buruh dengan

\footnotetext{
${ }^{8}$ Lalu Husni, Op.Cit. Hal 188.

${ }^{9}$ Ibid.

${ }^{10}$ Much. Nurachmad, Op.Cit. Hal.13.

${ }^{11}$ Redaksi RAS, Op.Cit., Hal 96.
} 
pekerja/buruh yang dipekerjakannya. ${ }^{12}$ Dalam bidang manajemen, outsourcing diberikan pengertian pendelegasian operasi dan manajemen harian suatu proses bisnis pada pihak luar (perusahaan penyedia jasa outsourcing). Outsourcing awalnya merupakan istilah dalam dunia bisnis untuk memenuhi kebutuhan tenaga kerja suatu perusahaan dengan mendatangkan dari luar perusahaan. ${ }^{13}$ Perusahaan penyedia pekerja/buruh harus memenuhi syarat sebagai berikut: ${ }^{14}$

a. Adanya hubungan kerja pekerja/buruh dan perusahaan penyedia jasa pekerja/buruh.

b. Perjanjian kerja yang berlaku dalam hubungan kerja sebagaimana yang dimaksud pada huruf a adalah perjanjian kerja untuk waktu tertentu yang memenuhi persyaratan sebagaimana dimaksud dalam Pasal 59 dan/atau perjanjian kerja waktu tidak tentu yang dibuat secara tertulis dan ditandatangani oleh kedua belah pihak.

c. Perlindungan upah dan kesejahteraan, syarat-syarat kerja, serta perselisihan yang timbul menjadi tanggung jawab perusahaan penyedia jasa pekerja/buruh.

Perjanjian antara perusahaan pengguna jasa pekerja/buruh dan perusahaan lain yang bertindak sebagai perusahaan penyedia jasa pekerja/buruh dibuat secara tertulis dan wajib memuat pasal-pasal sebagaimana yang dimaksud dalam Undang-Undang Nomo 13 Tahun 2003 tentang Ketenagakerjaan.

Selain itu, berdasarkan Peraturan Menteri Tenaga Kerja dan Transmigrasi No.

12 M. Fauzi, 2006, Aspek Hukum Penyerahan Sebagian Pelaksanaan Pekerjaan Kepada Perusahaan Lain (outsourcing), Risalah Hukum Fakultas Hukum Unmul, 021-969X. Vol.2, No.2 :Hal 89.

13 Lalu Husni, Op.Cit. Hal 188.

${ }^{14}$ Ibid. Hal 191
KEP-101/MEN/VI/2004 tentang Tata Cara Perizinan Perusahaan Penyedia Jasa Pekerja/Buruh disebutkan bahwa apabila perusahaan penyedia jasa memperoleh pekerjaan dari perusahaan pemberi pekerjaan, kedua belah pihak wajib membuat perjanjian tertulis yang sekurangkurangnya memuat: ${ }^{15}$

a. Jenis pekerjaan yang akan dilakukan oleh pekerja/buruh dari perusahaan penyedia jasa;

b. Penegasan bahwa dalam melaksanakan pekerjaan sebagaimana yang dimaksud huruf a, hubungan kerja yang terjadi adalah antara perusahaan penyedia jasa dengan pekerja/buruh yang dipekerjakan perusahaan penyedia jasa sehingga perlindungan, upah dan kesejahteraan, syarat-syarat kerja serta perselisihan yang timbul menjadi tanggung jawab perusahaan penyedia jasa pekerja/buruh;

c. Penegasan bahwa perusahaan penyedia jasa pekerja/buruh bersedia menerima pekerja/buruh dari perusahaan penyedia jasa pekerja/buruh sebelumnya untuk jenis-jenis pekerjaan yang terusmenerus ada di perusahaan pemberi kerja, dalam hal terjadi penggantian perusahaan penyedia jasa pekerja/buruh.

Undang-Undang Nomor 13 Tahun 2003 tentang Ketenagakerjaan tidak pernah ditemukan kata outsourcing secara langsung, namun Undang-undang ini merupakan tonggak baru yang mengatur dan mendelegasi permasalahan outsourcing. Istilah yang dipakai dalam undang-undang ini adalah perjanjian pemborongan pekerjaan atau penyedia jasa pekerja atau buruh. Istilah tersebut diadopsi dari istilah yang dipakai dalam KUHPerdata seperti sebagaimana telah

${ }^{15}$ Ibid. 
dijelaskan diatas. Lebih spesifik ketentuan yang mengatur outsourcing dapat ditemukan dalam Pasal 64 sampai dengan Pasal 66 Undang-Undang Nomor 13 Tahun 2003 tentang Ketenagakerjaan. ${ }^{16}$

Undang-Undang Nomor 13 Tahun 2003 tentang Ketenagakerjaan Pasal 64 disebutkan perusahaan dapat menyerahkan sebagian pelaksanaan pekerjaan kepada perusahaan lainnya melalui perjanjian pemborongan pekerjaan atau penyedia jasa pekerja/buruh. ${ }^{17}$ Selanjutnya dalam Pasal 65 yang intinya menyatakan bahwa penyerahan sebagian pelaksanaan pekerjaan kepada perusahaan lain dilaksanakan melalui perjanjian pemborongan pekerjaan yang dibuat secara tertulis. Pengaturan lebih lanjut mengenai peraturan ini ditetapkan melalui Keputusan Menteri Tenaga Kerja dan Transmigrasi No. Kep. 220/Men/X/2004 tentang SyaratSyarat Penyerahan Sebagian Pelaksanaan Pekerjaan Kepada Perusahaan Lain. ${ }^{18}$ Dan Pasal 66 mengatakan bahwa pekerjaan yang dapat dijadikan dalam perjanjian outsourcing adalah pekerjaan-pekerjaan yang tidak berhubungan langsung dengan kegiatan pokok atau proses produksi dari suatu perusahaan, kecuali untuk kegiatan yang tidak berhubungan langsung dengan proses produksi. ${ }^{19}$ Pada Pasal 66 ayat (1) dijelaskan bahwa pekerjaan yang berhubungan dengan kegiatan usaha pokok atau kegiatan yang berhubungan langsung dengan proses produksi, pengusaha hanya diperbolehkan mempekerjakan pekerja/buruh dengan perjanjian kerja waktu tertentu (PKWT) dan/atau perjanjian

16 N.L.M. Mahendrawati, 2009, Perjanjian Outsourcing Dalam Kegiatan Bisnis, Kertha Wicaksana, Vol.15. No 2: Hal. 151.

${ }^{17}$ Lalu Husni, Op.Cit., Hal 189.

${ }^{18}$ Much. Nurachmad, Loc.Cit.

19 Bungasan Hutapea, 2010, Perlindungan Hukum Menurut Undang-Undang Nomor 13 Tahun 2003 tentang Ketenagakerjaan Bagi Pekerja Dalam Perjanjian Outsourcing, Jurnal Penelitian Hukum APHI, DE JURE, 1410-5632 Vol.10. No. 3: Hal.297. waktu tidak tertentu (PKWTT). Yang dimaksud kegiatan jasa penunjang yang tidak berhubungan langsung dengan proses produksi adalah kegiatan yang berhubungan di luar usaha pokok (core business) suatu perusahaan. Kegiatan tersebut antara lain: usaha pelayanan kebersihan (cleaning service), usaha penyedia makanan bagi pekerja/buruh (catering), usaha tenaga pengamanan (security/satuan pengamanan), usaha jasa penunjang di pertambangan dan perminyakan, serta usaha penyediaan angkutan pekerja/buruh. Juga Pasal 66 ayat (2) huruf (c) dijelaskan bahwa perlindungan upah dan kesejahteraan, syarat-syarat kerja maupun penyelesaian perselisihan antara penyedia jasa tenaga kerja dengan pekerja/buruh harus sesuai dengan peraturan perundang-undangan yang berlaku. Pekerja/buruh yang bekerja pada perusahaan penyedia jasa pekerja/buruh memperoleh hak (yang sama) sesuai dengan perjanjian kerja, peraturan perusahaan atau perjanjian kerja bersama atas perlindungan upah dan kesejahteraan, syarat-syarat kerja, serta perselisihan yang timbul dengan pekerja/buruh lainnya di perusahaan pengguna jasa pekerja/buruh. ${ }^{20}$

Perjanjian kerja dapat dibuat dalam bentuk lisan dan/atau tertulis (pasal 51 ayat (1) Undang-Undang Nomor 13 Tahun 2003 tentang Ketenagakerjaan). Secara normatif bentuk tertulis menjamin kepastian hak dan kewajiban para pihak, sehingga jika terjadi perselisihan akan sangat membantu proses pembuktian. Namun tidak dapat dipungkiri masih banyak perusahaanperusahaan yang tidak atau membuat perjanjian kerja secara tertulis disebabkan karena ketidakmampuan sumber daya manusia maupun karena kelaziman, sehingga atas dasar kepercayaan membuat

20 Anonimous, 2011, ketenagakerjaan \& Penyelesaian Perselisihan Hubungan Industrial, Jakarta, Penerbit: Indonesia Legal Center Publishing For Law and Justice Reform, Hal 106-107. 
perjanjian kerja secara lisan. ${ }^{21}$ Jangka waktu perjanjian kerja dapat dibuat waktu tertentu bagi hubungan kerja yang dibatasi jangka waktu berlakunya, dan waktu tidak tertentu bagi hubungan kerja yang tidak dibatasi jangka waktu berlakunya atau selesainya pekerjaan tertentu. Perjanjian kerja yang dibuat untuk waktu tertentu lazimnya disebut dengan perjanjian kerja kontrak atau perjanjian kerja tidak tetap. Status pekerjanya adalah pekerja kontrak. Sedangkan perjanjian kerja waktu tidak tertentu biasanya disebut perjanjian kerja tetap dan status pekerjanya adalah pekerja tetap. ${ }^{22}$ Dan masa percobaan adalah masa atau waktu untuk menilai kinerja dan kesungguhan, keahlian seorang pekerja. Lama masa percobaan adalah tiga bulan, dalam masa percobaan pengusaha dapat mengakhiri hubungan kerja secara sepihak (tanpa izin dari pejabat yang berwenang) dalam ketentuan ini tidak dibolehkan melaksanakan masa percobaan kepada pekerja waktu tertentu karena perjanjian kerja berlangsung relatif singkat. ${ }^{23}$

Undang-Undang Ketenagakerjaan dalam beberapa pasalnya memasung hak fundamental pekerja/buruh dan serikat pekerja/buruh, bertentangan dengan Pasal 28 UUD 1945 yang menjamin kemerdekaan berserikat dan berkumpul, mengeluarkan pikiran dengan lisan dan tulisan, ${ }^{24}$ maka agar suatu peraturan perundang-undangan berlaku efektif, maka secara substansial harus memperhatikan beberapa asas yaitu: ${ }^{25}$

1. Undang-Undang tidak boleh berlaku surut, artinya Undang-Undang hanya boleh diterapkan terhadap peristiwa yang disebut dalam Undang-Undang

\footnotetext{
${ }^{21}$ Lalu Husni, Op.Cit., Hal 69.

22 Ibid., Hal 70.

${ }^{23}$ Ibid., hal 70-71.

24 Agusmidah, 2011, Dilematika Hukum Ketenagakerjaan Tinjauan Politik, Medan, Penerbit: PT. Sofmedia, Hal. 95.

${ }^{25}$ Lalu Husni, Op.Cit. Hal 35.
}

tersebut serta terjadi setelah UndangUndang itu dinyatakan berlaku.

2. Undang-Undang dibuat oleh penguasa yang lebih tinggi mempunyai kedudukan yang lebih tinggi pula (lex superior derogat lex impriori).

3. Undang-Undang yang bersifat khusus mengesampingkan Undang-Undang yang bersifat umum (lex specialis derogat lex generali), apabila pembuatannya sama, artinya terhadap peristiwa-peristiwa khusus wajib diberlakukan Undang-Undang yang menyebutkan peristiwa tersebut, walaupun bagi peristiwa khusus tersebut dapat pula diberlakukan undang-undang yang menyebutkan peristiwa yang lebih luas ataupun lebih umum, yang juga dapat mencakup peristiwa khusus tersebut.

4. Undang-undang baru mengalahkan undang-undang lama (lex posteriori derogat lex priori), artinya undangundang lain yang lebih dahulu beraku dan mengatur mengenai suatu hal tertentu, tidak berlaku lagi apabila telah ada undang-undang baru yang berlaku belakangan dan mengatur hal tertentu tersebut, akan tetapi makna dan tujuannya berlainan atau berlawanan dengan undang-undang yang lama tersebut.

5. Undang-undang tidak dapat diganggu gugat, artinya adalah undang-undang hanya dapat dicabut dan atau diubah oleh lembaga yang membuatnya. Di Indonesia, Mahkamah Agung diberikan wewenang untuk menguji secara materiil hanya terhadap peraturan perundang-undangan di bawah undang-undang saja. Kewenangan tersebut mengandung makna bahwa Mahkamah Agung dapat menyatakan bahwa suatu peraturan tertentu di bawah undang- 
undang tidak mempunyai kekuatan hukum (harus ditinjau kembali) karena bertentangan dengan peraturan di atasnya.

6. Undang-undang merupakan sarana untuk mencapai kesejahteraan spiritual dan material bagi masyarakat maupun pribadi melalui pelestarian atau pembaharuan (inovasi).

Kewajiban merupakan suatu tugas tanggungjawab dari para pihak, adapun kewajiban dari pekerja/buruh seperti yang telah diatur dalam KUHPerdata Pasal 1603, Pasal 1603a, Pasal 1603b dan Pasal 1603c yang pada intinya adalah sebagai berikut: ${ }^{26}$

1. Pekerja/buruh wajib melakukan pekerjaan, melakukan pekerjaan adalah tugas utama dari seorang pekerja yang harus dilakukan sendiri, meskipun demikian dengan seizin pengusaha dapat diwakilkan. Untuk itulah mengingat pekerjaan yang dilakukan oleh pekerja yang sangat pribadi sifatnya karena berkaitan dengan keahliannya, maka berdasarkan ketentuan peraturan perundang-undangan jika pekerja meninggal dunia, maka hubungan kerja berakhir dengan sendirinya (PHK demi hukum).

2. Pekerja/buruh wajib menaati aturan dan petunjuk dari pengusaha, dalam melakukan pekerjaan pekerja/buruh wajib menaati petunjuk yang diberikan oleh pengusaha. Aturan yang wajib ditaati oleh pekerja/buruh sebaiknya dituangkan dalam peraturan perusahaan sehingga menjadi jelas ruang lingkup dari petunjuk tersebut.

3. Kewajiban ganti rugi dan denda, jika pekerja/buruh melakukan perbuatan yang merugikan perusahaan baik karena kesengajaan atau kelalaian, maka sesuai dengan prinsip hukum pekerja/buruh wajib ganti rugi dan denda.

Dan yang menjadi kewajiban pengusaha pada intinya yaitu sebagai berikut: ${ }^{27}$

1. Kewajiban membayar upah, dalam hubungan kerja kewajiban utama bagi pengusaha adalah membayar upah kepada pekerjanya secara tepat waktu. Ketentuan tentang upah ini juga telah mengalami perubahan pengaturan ke arah hukum publik. Hal ini terlihat dari campur tangan pemerintah dalam menetapkan besarnya upah terendah yang harus dibayar oleh pengusaha yang dikenal dengan upah minimum, maupun pengaturan upah dalam Peraturan Pemerintah No. 8 Tahun 1981 tentang Perlindungan Upah. Campur tangan pemerintah dalam menetapkan besarnya upah ini penting guna menjaga agar jangan sampai besarnya upah yang diterima oleh pekerja terlampau rendah sehingga tidak dapat memenuhi kebutuhan hidup pekerja meskipun secara minimum

2. Kewajiban memberikan istirahat/cuti, pihak pengusaha diwajibkan untuk memberikan istirahat tahunan kepada pekerja secara teratur. Hak atas istirahat ini penting artinya untuk menghalangkan kejenuhan pekerja dalam melakukan pekerjaan. Dengan demikian diharapkan gairah kerja akan tetap stabil. Cuti tahunan yang lamanya 12 hari kerja. Selain itu pekerja juga berhak atas cuti panjang selama 2 bulan setelah bekerja terus menerus selama 6 tahun pada suatu perusahaan (Pasal 79 Undang-Undang Nomor 13 Tahun 2003 tentang Ketenagakerjaan) 
3. Kewajiban mengurus perawatan dan pengobatan, pengusaha wajib mengurus perawatan/pengobatan bagi pekerja yang bertempat tinggal di rumah majikan (Pasal 1602x KUHPerdata). Dalam perkembangan hukum ketenagakerjaan, kewajiban ini tidak hanya terbatas bagi pekerja yang bertempat tinggal di rumah majikan, tetapi juga bagi pekerja yang tidak bertempat tinggal di rumah majikan. Perlindungan bagi tenaga kerja yang sakit, kecelakaan, kematian telah dijamin melalui perlindungan Jamsostek sebagaimana diatur dalam Undang-Undang Nomor 3 Tahun 1992 tentang Jamsostek

4. Kewajiban memberikan surat keterangan, kewajiban ini didasarkan pada ketentuan Pasal 1602a KUHPerdata yang menentukan bahwa majikan/pengusaha wajib memberikan surat keterangan yang diberi tanggal dan dibubuhi tanda tangan. Dalam surat keterangan tersebut dijelaskan mengenai sifat pekerjaan yang dilakukan, lamanya hubungan kerja (masa kerja). Surat keterangan itu juga diberikan meskipun inisiatif pemutusan hubungan kerja datangnya dari pihak pekerja. Surat keterangan tersebut sangat penting artinya sebagai bekal pekerja dalam mencari pekerjaan baru, sehingga dia diperlakukan sesuai dengan pengalamannya.

Jika dilihat substansi yang diatur dalam Undang-Undang Nomor 13 Tahun 2003 tentang Ketenagakerjaan ini tampak bahwa Undang-Undang ini menyatukan berbagai peraturan perundang-undangan yang selama ini pengaturannya masih tersebar dalam berbagai peraturan perundangundangan, baik yang menyangkut upah, norma kerja, penempatan tenaga kerja dan hubungan kerja, $^{28}$ namun dalam peraturan Menteri Tenaga Kerja No.02/Men/1967 disebutkan bahwa peraturan perusahaan adalah suatu peraturan yang dibuat oleh pimpinan perusahaan yang memuat ketentuan-ketentuan tentang syarat-syarat kerja yang berlaku pada perusahaan yang bersangkutan dan memuat tata tertib perusahaan. Sejalan dengan pengertian tersebut dalam Undang-Undang Nomor 13 Tahun 2003 tentang Ketenagakerjaan juga memberikan pengertian peraturan perusahaan adalah peraturan yang dibuat secara tertulis oleh pengusaha yang memuat syarat-syarat kerja serta tata tertib perusahaan, ${ }^{29}$ dalam pengertian tersebut jelas bahwa peraturan perusahaan dibuat secara sepihak oleh pengusaha yang berisikan syarat kerja, hak dan kewajiban pekerja dan pengusaha dan tata tertib perusahaan, $^{30}$ sehingga seringkali peraturan perusahaan bertentangan dengan Undang-Undang Dasar 1945 serta Undang-Undang Nomor 13 Tahun 2003 tentang Ketenagakerjaan yang merugikan hak-hak pekerja/buruh dan juga sangat disayangkan kurangnya pengetahuan ilmu hukum dari pekerja/buruh dan kurangnya pengawasan dari pihak pemerintah sehingga banyak pengusaha/perusahaan yang membuat peraturan perusahaan melenceng dari peraturan yang telah dibuat oleh pemerintah. Hal-hal tersebut pastinya merugikan pekerja/buruh.

Perbedaan peraturan perusahaan dan peraturan pemerintah mengakibatkan perselisihan antara pengusaha dan pekerja/buruh mengenai hak dan kewajiban para pihak, juga perselisihan kepentingan dan perselisihan pemutusan hubungan kerja serta perselisihan antar serikat pekerja/serikat buruh dalam suatu perusahaan.

\footnotetext{
28 Ibid. Hal 29.

${ }^{29}$ Ibid. Hal 89.

${ }^{30}$ Ibid.
} 


\section{B. IMPLEMENTASI PERLINDUNGAN TENAGA KERJA OUTSOURCING PASCA PUTUSAN MAHKAMAH KONSTITUSI NOMOR 27/PUU- IX/2011}

Mahkamah Konstitusi (MK) merupakan salah satu lembaga peradilan di Indonesia. Berdasarkan ketentuan Pasal 24C ayat (1) dan (2) UUD 1945, yang kemudian diatur pula dalam Pasal 10 ayat (1) dan (2) Undang-Undang Nomor 24 Tahun 2003 tentang Mahkamah Konstitusi (UU MK), Mahkamah Konstitusi memiliki empat kewenangan dan satu kewajiban. Keempat kewenangan tersebut adalah mengadili pada tingkat pertama dan terakhir untuk menguji Undang-Undang terhadap UndangUndang Dasar, memutus sengketa kewenangan lembaga negara yang kewenangannya diberikan oleh UndangUndang Dasar, memutus pembubaran partai politik, dan memutus perselisihan tentang pemilihan umum. Sedangkan kewajiban Mahkamah Konstitusi adalah memberikan putusan atas pendapat Dewan Perwakilan Rakyat mengenai dugaan pelanggaran oleh Presiden dan/atau Wakil Presiden menurut Undang-Undang Dasar. ${ }^{31}$

Putusan Mahkamah Konstitusi bersifat final dan mengikat. Dalam putusan Mahkamah Konstitusilah dapat diketahui apakah suatu Undang-Undang yang dimohonkan bertentangan atau tidak dengan Undang-Undang Dasar. Hal ini dengan sendirinya berarti bahwa putusan Mahkamah Konstitusi memuat bagaimana suatu ketentuan dalam Undang-Undang Dasar 1945 ditafsirkan terkait dengan ketentuan Undang-Undang yang dimohonkan tersebut. Di sisi lain, karena putusan Mahkamah Konstitusi bersifat final dan mengikat, maka putusan Mahkamah

\footnotetext{
31 Anonimous, 2006, Menegakan Negara Hukum Yang Demokratis, Penerbit Sekretariat Jendral dan Kepaniteraan Mahkamah Konstitusi, Hal 34.
}

Konstitusi yang mengabulkan suatu permohonan pengujian Undang-Undang terhadap Undang-Undang Dasar, baik mengabulkan sebagian maupun seluruhnya, dengan sendirinya telah mengubah ketentuan suatu UndangUndang dengan menyatakan bertentangan dengan UUD 1945 dan tidak memiliki kekuatan hukum mengikat. Oleh karena itulah putusan yang mengabulkan tersebut harus dimuat dalam Berita Negara dalam waktu 30 hari sejak dibacakan agar diketahui masyarakat umum. Putusan Mahkamah Konstitusi mulai berlaku sejak saat setelah dibacakan dalam sidang pleno pembacaan putusan yang terbuka untuk umum. Bagi putusan yang mengabulkan permohonan, hal ini berarti sejak setelah pembacaan putusan tersebut, ketentuan Undang-Undang yang dibatalkan tidak berlaku lagi sehingga setiap penyelenggara negara dan warga negara tidak lagi dapat menjadikan sebagai dasar hukum kebijakan atau tindakan. ${ }^{32}$ Dari sinilah bisa kita ketahui bersama berdasarkan UndangUndang Nomor 24 Tahun 2003 tentang Mahkamah Konstitusi, negara memberi wewenang kepada Mahkamah Konstitusi untuk menguji Undang-Undang yang bertentangan dengan Undang-Undang Dasar 1945 yang merupakan UndangUndang tertinggi di Indonesia dan putusan dari Mahkamah Konstitusi bersifat final dan mengikat.

Tanggal 21 Maret 2011, Didik Suprijadi bertindak sebagai ketua umum Aliansi Petugas Pembaca Meter Listrik Indonesia (AP2ML) melalui kuasa hukum mengajukan permohonan peninjauan Undang-Undang Nomor 13 Tahun 2003 tentang Ketenagakerjaan Pasal 59 yang mengatur tentang Perjanjian Kerja Waktu Tertentu (pekerja kontrak) dan Pasal 64 yang mengatur tentang penyerahan sebagian pelaksanaan pekerjaan kepada perusahaan

\footnotetext{
32 Ibid., Hal 35.
} 
lainnya (outsourcing) yang memiliki dampak langsung dan tidak langsung kepada semua buruh/pekerja kontrak dan buruh/pekerja outsourcing yang ada di Indonesia dan sangat merugikan hak-hak konstitusionalnya yang diatur dalam UUD 1945, yaitu mengenai hak atas pekerjaan dan penghidupan yang layak bagi kemanusiaan, hak untuk bekerja serta mendapat imbalan dan perlakuan yang adil dan layak dalam hubungan kerja dan hak atas kesejahteraan dan kemakmuran. Yang telah di terima dan terdaftar di Kepaniteraan Mahkamah Konstitusi pada hari Senin, tanggal 4 April 2011 berdasarkan Akta Penerimaan Berkas Permohonan Nomor 127/PAN.MK/2011 dan diregistrasi pada hari Senin tanggal 4 April 2011 dengan Nomor 27/PUU-IX/2011, yang telah diperbaiki dan diterima di Kepaniteraan Mahkamah pada tanggal 11 Mei 2011.

Alasan dari Aliansi Petugas Pembaca Meter Listrik Indonesia (AP2ML) yang dimuat dalam Putusan Mahkamah Konstitusi No. 27/PUU-IX/2011 tersebut yaitu: ${ }^{33}$

1. Penekanan terhadap efisiensi secara berlebihan untuk semata-mata meningkatkan investasi guna mendukung pembangunan ekonomi melalui kebijakan upah murah ini berakibat pada hilangnya keamanan kerja (job security) bagi buruh/pekerja Indonesia, karena sebagian besar buruh/pekerja tidak akan lagi menjadi buruh/pekerja tetap, tetapi menjadi buruh/pekerja kontrak yang akan berlangsung seumur hidupnya. Hal inilah yang oleh sebagian kalangan disebut sebagai satu bentuk perbudakan zaman modern.

\footnotetext{
33 Vide Putusan MK No. 27/PUU-IX/2011 Perihal Pengujian Undang-Undang Nomor 13 tahun 2003 tentang ketenagakerjaan Terhadap Undang-Undang Dasar Negara Rebuplik Indonesia 1945.
}

2. Bahwa status sebagai buruh/pekerja kontrak ini pada kenyataannya berarti juga hilangnya hak-hak, tunjangan-tunjangan kerja, jaminanjaminan kerja dan sosial yang biasanya dinikmati oleh mereka yang mempunyai status sebagai buruh/pekerja tetap, yang dengan demikian amat potensial menurunkan kualitas hidup dan kesejahteraan buruh/pekerja Indonsia dan karenanya buruh/pekerja merupakan bagian terbesar dari rakyat Indonesia, pada akhirnya juga akan menurunkan kualitas hidup dan kesejahteraan rakyat Indonesia pada umumnya.

3. Dalam hubungan kerja berdasarkan Perjanjian Kerja Waktu Tertentu (PKWT) sebagaimana diatur dalam Pasal 59 Undang-Undang Nomor 13 Tahun 2003 dan penyerahan sebagian pekerjaan kepada perusahaan lain (outsourcing) sebagaimana juga diatur dalam Pasal 64 Undang-Undang Nomor 13 Tahun 2003, buruh/pekerja dilihat semata-mata sebagai komoditas atau barang dagangan, di sebuah pasar tenaga kerja. Buruh/pekerja dibiarkan sendirian menghadapi ganasnya kekuatan pasar dan kekuatan modal, yang akhirnya akan timbul kesenjangan sosial yang semakin menganga antara yang kaya dan yang miskin dan tidak menutup kemungkinan kelak anak cucu kita akan menjadi budak di negeri sendiri dan diperbudak oleh bangsa sendiri dan ini jelas bertentangan dengan Pasal 27 ayat (2) UUD 1945, "Setiap warga negara berhak atas pekerjaan dan penghidupan yang layak bagi kemanusiaan". Dan Pasal 28D ayat (2) "Setiap orang berhak untuk bekerja serta mendapat imbalan 
dan perlakuan yang adil dan layak dalam hubungan kerja".

4. Dalam hubungan kerja berdasarkan Perjanjian Kerja Waktu Tertentu (PKWT) sebagaimana diatur dalam Pasal 59 Undang-Undang Nomor 13 Tahun 2003 dan penyerahan sebagian pekerjaan kepada perusahaan lain sebagaimana juga diatur dalam Pasal 64 UndangUndang Nomor 13 Tahun 2003 (outsourcing) buruh/pekerja ditempatkan sebagai faktor produksi semata, dengan begitu mudah dipekerjakan bila dibutuhkan dan diputus hubungan kerjanya ketika tidak dibutuhkan lagi. Dengan demikian komponen upah sebagai salah satu dari biaya-biaya (cost) bisa tetap ditekan seminimal mungkin. Inilah yang akan terjadi dengan dilegalkannya sistem kerja "pemborongan pekerjaan" (outsourcing), yang akan menjadikan buruh/pekerja semata sebagai sapi perahan para pemilik modal dan ini adalah bertentangan dengan Pasal 33 ayat (1) UUD 1945 yang menyatakan "Perekonomian disusun sebagai usaha bersama berdasar atas asas kekeluargaan". Di dalam penjelasannya ditegaskan lagi bahwa ini artinya perekonomian kita berdasarkan pada demokrasi ekonomi, dimana produksi dikerjakan oleh semua, untuk semua dengan kemakmuran masyarakatlah yang diutamakan. Disinilah persis perbudakan modern dan degradasi nilai manusia, buruh/pekerja sebagai komoditas atau barang dagangan, akan terjadi secara resmi dan diresmikan melalui sebuah Undang-Undang. Kemakmuran masyarakat yang diamanatkan konstitusi pun akan menjadi kata- kata kosong atau merupakan hiasan kata mutiara saja.

5. Sistem outsourcing, konstruksi hukumnya yaitu adanya suatu perusahaan jasa pekerja merekrut calon pekerja untuk ditempatkan di perusahaan pengguna. Jadi disini diawali suatu hubungan hukum atau suatu perjanjian antara perusahaan penyedia jasa pekerja dengan perusahaan pengguna pekerja. Perusahaan penyedia jasa pekerja mengikatkan dirinya untuk menempatkan pekerja di perusahaan pengguna dan perusahaan pengguna mengikatkan dirinya untuk menggunakan pekerja tersebut. Berdasarkan perjanjian penempatan tenaga kerja, perusahaan penyedia jasa pekerja akan mendapatkan sejumlah uang dari pengguna. Untuk 100 orang misalnya Rp. 10.000.000, kemudian perusahaan penyedia jasa pekerja akan mengambil sekian persen, sisanya dibayarkan kepada pekerja yang bekerja di perusahaan pengguna. Jadi konstruksi hukum semacam ini merupakan perbudakan, karena pekerja-pekerja tersebut dijual kepada pengguna dengan jumlah uang. $\mathrm{Hal}$ ini merupakan perbudakan modern.

6. Di lain pihak outsourcing juga menggunakan Perjanjian Kerja Waktu Tertentu. Perjanjian Kerja Waktu Tertentu jelas tidak menjamin adanya job security, tidak adanya kelangsungan pekerjaan karena seorang pekerja dengan Perjanjian Kerja Waktu Tertentu pasti tahu bahwa pada suatu saat hubungan kerja akan putus dan tidak akan bekerja lagi di situ, akibatnya pekerja akan mencari pekerjaan lain lagi. Sehingga kontinitas pekerjaan menjadi 
persoalan bagi pekerja yang di outsourcing dengan Perjanjian Kerja Waktu Tertentu. Kalau job security tidak terjamin, jelas bertentangan dengan Pasal 27 ayat (2) UUD 1945 yaitu hak untuk mendapatkan pekerjaan yang layak.

7. Outsourcing di dalam Pasal 64 menunjukkan adanya dua macam outsourcing, yaitu outsourcing mengenai pekerjaannya yang dilakukan oleh pemborong dan outsourcing mengenai pekerjanya yang dilakukan oleh perusahaan jasa pekerja. Outsourcing yang pertama mengenai pekerjaan, konstruksi hukumnya yaitu ada main contractor yang mensubkan pekerjaan pada sub contractor. Sub contractor untuk melakukan pekerjaan yang di subkan oleh main contractor yang membutuhkan pekerja. Di situlah sub contractor merekrut pekerja untuk mengerjakan pekerjaan yang disubkan oleh main contractor. Sehingga ada hubungan kerja antara sub contractor nya dengan pekerjanya.

8. Bahwa kalau dikaitkan dengan konstitusi, jelas hal ini memaksakan adanya hubungan kerja antara perusahaan penyedia jasa pekerja dengan pekerjanya, yang sebenarnya tidak memenuhi unsurunsur hubungan kerja yaitu adanya perintah, pekerjaan dan upah, maka menunjukkan bahwa pekerja hanya dianggap sebagai barang saja bukan sebagai subjek hukum.

9. Bahwa perbudakan terhadap outsourcing mutlak, karena di sini perusahaan penyedia jasa pekerja pada dasarnya menjual manusia kepada user. Dengan sejumlah uang akan mendapatkan keuntungan dengan menjual manusia.
10. Bahwa Pasal 59 dan Pasal 64 Undang-Undang Nomor 13 Tahun 2003 tentang Ketenagakerjaan tidak sesuai dengan Pasal 27 ayat (2), Pasal 28D ayat (2) dan Pasal 33 ayat (1) UUD 1945, karena manusia yang harus dilindungi adalah manusia yang seutuhnya. Bekerja seharusnya adalah untuk memberikan kehidupan yang selayaknya tetapi ketika itu pekerja hanya sebagai bagian produksi dan terutama dengan kontrak-kontrak yang dibuat, maka hanya sebagai salah satu bagian dari produksi, sehingga perlindungan sebagai manusia menjadi lemah.

11. Bahwa berdasarkan fakta-fakta alasan di atas, jelas bahwa permohonan ini disampaikan secara meyakinkan dan patut, karena berangkat dari keprihatinan nyata sebagian besar buruh/pekerja maupun, sehingga patut kiranya Mahkamah berkenan melaksanakan haknya untuk melakukan pengujian Pasal 59 dan Pasal 64 UndangUndang Nomor 13 Tahun 2003 tentang Ketenagakerjaan terhadap Pasal 27 ayat (2), Pasal 28D ayat (2) dan Pasal 33 ayat (1) UUD 1945.

12. Bahwa karena Pasal 65 dan Pasal 66 Undang-Undang Nomor 13 Tahun 2003 tentang Ketenagakerjaan ada kaitannya dengan Pasal 64 UndangUndang Nomor 13 Tahun 2003 tentang Ketenagakerjaan, maka dengan sendirinya Pasal 65 dan Pasal 66 Undang-Undang Nomor 13 Tahun 2003 tentang Ketenagakerjaan juga bertentangan dengan Pasal 27 ayat (2), Pasal 28D ayat (2) dan Pasal 33 ayat (1) UUD 1945.

Selain alasan, pemohon juga menuntut agar Mahkamah Konstitusi dapat 
mengabulkan tuntutan mereka yang pada intinya menyatakan bahwa Pasal 59 dan 64 Undang-Undang Nomor 13 Tahun 2003 tentang Ketenagakerjaan bertentangan dengan Undang-Undang Dasar 1945 karena menurut Pemohon ketentuan Pasal 59 dan Pasal 64 Undang-Undang Ketenagakerjaan, yang pada intinya mengatur tentang penyerahan sebagian pekerjaan kepada perusahaan lain (outsourcing), maka buruh/pekerja dilihat semata-mata sebagai komoditas atau barang dagangan di sebuah pasar tenaga kerja, selain itu pekerja/buruh ditempatkan sebagai faktor produksi semata, dengan begitu mudah dipekerjakan bila dibutuhkan dan diputus hubungan kerjanya ketika tidak dibutuhkan lagi, yang pada gilirannya komponen upah dapat ditekan seminimal mungkin, bahwa outsourcing adalah suatu bentuk pemaksaan kerja antara perusahaan penyedia jasa pekerja dengan pekerjanya, yang sebenarnya tidak memenuhi unsurunsur hubungan kerja yaitu adanya perintah, pekerjaan dan upah, maka hal ini menunjukkan bahwa pekerja hanya dianggap sebagai barang saja bukan sebagai subjek hukum, karena itu menurut Pemohon, Pasal 59 dan Pasal 64 UndangUndang Ketenagakerjaan, yang dengan sendirinya juga terkait dengan ketentuan Pasal 65 dan Pasal 66, dianggap bertentangan dengan ketentuan Pasal 27 ayat (2), Pasal 28D ayat (2) dan Pasal 3 ayat (1) UUD 1945 juga pada Pasal 59, Pasal 64, Pasal 65, Pasal 66 Undang-Undang Nomor 13 Tahun 2003 tentang Ketenagakerjaan tidak mempunyai hukum yang mengikat.

Uraian tersebut di atas menurut Pemerintah, ketentuan Pasal 59 UndangUndang Ketenagakerjaan telah sejalan dengan amanat konstitusi khususnya yang terkait dengan hak setiap orang untuk memperoleh pekerjaan dan penghasilan yang layak, karena itu ketentuan a quo tidak bertentangan dengan ketentuan Pasal 27 ayat (2), Pasal 28D ayat (2) dan Pasal 33 ayat (1) UUD 1945, juga tidak merugikan hak dan/atau kewenangan konstitusional Pemohon. Juga DPR berpandangan bahwa ketentuan Pasal 59 dan Pasal 64 UndangUndang Nomor 13 Tahun 2003 tentang Ketenagakerjaan tidak menghambat dan merugikan hak konstitusional para Pemohon sebagaimana dijamin Pasal 27 ayat (2), Pasal 28D ayat (2), Pasal 33 ayat (1) UUD 1945.

Sehingga pada tanggal 5 januari 2012 oleh sembilan Hakim Konstitusi yaitu Moh. Mahfud MD, selaku Ketua merangkap Anggota, Achmad Sodiki, Hamdan Zoelva, Muhammad Alim, Ahmad Fadlil Sumadi, Anwar Usman, Harjono, Maria Farida Indrati, dan M. Akil Mochtar, masingmasing sebagai Anggota, memutuskan sebagai berikut: ${ }^{34}$

- Mengabulkan permohonan Pemohon untuk sebagian;

- Frasa “...perjanjian kerja waktu tertentu" dalam Pasal 65 ayat (7) dan frasa "...perjanjian kerja untuk waktu tertentu" dalam Pasal 66 ayat (2) huruf b Undang-Undang Nomor 13 Tahun 2003 tentang Ketenagakerjaan (Lembaran Negara Republik Indonesia Tahun 2003 Nomor 39, Tambahan Lembaran Negara Republik Indonesia Nomor 4279) bertentangan dengan UndangUndang Dasar Negara Republik Indonesia Tahun 1945 sepanjang dalam perjanjian kerja tersebut tidak disyaratkan adanya pengalihan perlindungan hak-hak bagi pekerja/buruh yang objek kerjanya tetap ada, walaupun terjadi pergantian perusahaan yang melaksanakan sebagian pekerjaan borongan dari

\footnotetext{
34 Vide Putusan MK No. 27/PUU-IX/2011 Perihal Pengujian Undang-Undang Nomor 13 tahun 2003 tentang ketenagakerjaan Terhadap Undang-Undang Dasar Negara Rebuplik Indonesia 1945.
} 
perusahaan lain atau perusahaan penyedia jasa pekerja/buruh;

- Frasa "...perjanjian kerja waktu tertentu" dalam Pasal 65 ayat (7) dan frasa "...perjanjian kerja untuk waktu tertentu" dalam Pasal 66 ayat (2) huruf b Undang-Undang Nomor 13 Tahun 2003 tentang Ketenagakerjaan (Lembaran Negara Republik Indonesia Tahun 2003 Nomor 39, Tambahan Lembaran Negara Republik Indonesia Nomor 4279) tidak memiliki kekuatan hukum mengikat sepanjang dalam perjanjian kerja tersebut tidak disyaratkan adanya pengalihan perlindungan hak-hak bagi pekerja/buruh yang objek kerjanya tetap ada, walaupun terjadi pergantian perusahaan yang melaksanakan sebagian pekerjaan borongan dari perusahaan lain atau perusahaan penyedia jasa pekerja/buruh;

- Menolak permohonan Pemohon untuk selain dan selebihnya;

- Memerintahkan untuk memuat putusan ini dalam Berita Negara Republik Indonesia sebagaimana mestinya

Setelah adanya keputusan dari Mahkamah Konstitusi, dan untuk menindak lanjuti keputusan Mahkamah Konstitusi maka pemerintah dalam hal ini Kementerian Tenaga Kerja dan Transmigrasi Republik Indonesia lewat Direktorat Jenderal Pembinaan Hubungan Industrial dan Jaminan Sosial Tenaga Kerja mengeluarkan Surat Edaran Nomor: B. 31/PHIJSK/I/2012 tentang Pelaksanaan Putusan Mahkamah Konstitusi Nomor: 27/PUU-IX/2011. Surat Edaran tersebut ditujuhkan kepada Kepala Instansi yang bertanggung jawab di bidang Ketenagakerjaan Provinsi di seluruh
Indonesia. Adapun inti isi dari Surat Edaran tersebut sebagai berikut: ${ }^{35}$

1. Perjanjian Kerja Waktu Tertentu (PKWT) sebagaimana yang diatur dalam Pasal 59 Undang-Undang Nomor 13 Tahun 2003 tentang Ketenagakerjaan tetap berlaku.

2. Dalam hal perusahaan menerapkan sistem penyerahan sebagian pelaksanaan pekerjaan kepada perusahaan lain melalui perjanjian pemborongan pekerjaan atau penyediaan jasa pekerja/buruh sebagaimana diatur dalam Pasal 64, Pasal 65 dan Pasal 66 UndangUndang Nomor 13 Tahun 2003 tentang Ketenagakerjaan maka:

a. Apabila dalam perjanjian kerja antara perusahaan penerima pemborongan pekerjaan atau perusahaan penyedia jasa pekerja/buruh dengan pekerja/buruhnya tidak memuat syarat adanya pengalihan perlindungan hakhak bagi pekerja/buruh yang obyek kerjanya tetap ada (sama), kepada perusahaan penerima pemborongan pekerjaan lain atau perusahaan penyedia jasa pekerja/buruh lain, maka hubungan kerja antara perusahaan penerima pekerjaan borongan atau perusahaan penyedia jasa pekerja/buruh dengan pekerja/buruhnya harus didasarkan pada Perjanjian Kerja Waktu Tidak Tertentu (PKWTT).

b. Apabila dalam perjanjian kerja antara perusahaan penerima pemborongan pekerjaan atau

\footnotetext{
${ }^{35}$ Vide Surat Edaran Kementerian Tenaga Kerja dan Transmigrasi Nomor: Nomor: B.31/PHIJSK/I/2012 tentang Pelaksanaan Putusan Mahkamah Konstitusi Nomor: 27/PUU-IX/2011
} 


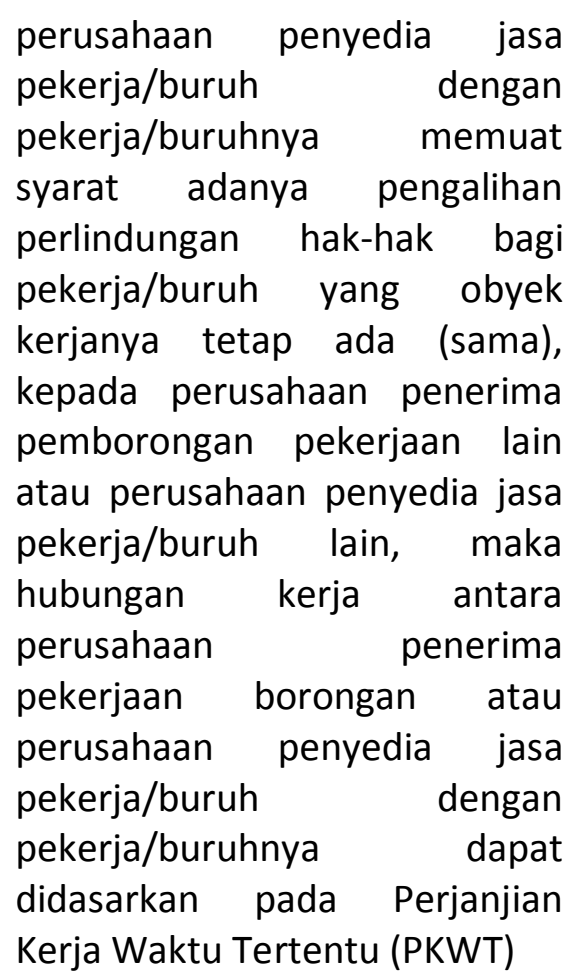

3. Dengan adanya putusan Mahkamah Konstitusi Nomor 27/PUU-IX/2011 tanggal 17 Januari 2012 tersebut, serta dengan mempertimbangkan keberadaan perjanjian kerja yang telah disepakati oleh kedua belah pihak sebelum diterbitkannya putusan Mahkamah Konstitusi ini, maka PKWT yang saat ini masih berlangsung pada perusahaan pemborongan pekerjaan atau perusahaan penyedia jasa pekerja/buruh, tetap berlaku sampai berakhirnya jangka waktu yang diperjanjikan.

Ketentuan dalam Undang-Undang Nomor 13 Tahun 2003 tentang Ketenagakerjaan yang mensyaratkan bahwa perusahaan outsourcing (pemborong pekerjaan atau penyediaan jasa pekerja/buruh) harus berbadan hukum ditujukan dalam rangka menjamin perlindungan hukum bagi pekerja/buruh yang dipekerjakan, namun sayangnya undang-undang ini tidak menyebut bentuk badan hukum dimaksud karena dalam ilmu hukum dikenal beberapa bentuk badan hukum seperti Perseroan Terbatas (PT),
Koperasi, yayasan sehingga dalam implementasinya ketentuan ini menimbulkan permasalahan. ${ }^{36}$

\section{DAFTAR PUSTAKA}

Anonimous, 2011, Ketenagakerjaan \& Penyelesaian Perselisihan Hubungan Industrial, Jakarta, Penerbit: Indonesia Legal Center Publishing For Law and Justice Reform

Anonimous, 2006, Menegakan Negara Hukum Yang Demokratis, Penerbit Sekretariat Jendral dan Kepaniteraan Mahkamah Konstitusi

Bahder Johan Nasution, 2004, Hukum Ketenagakerjaan Kebebasan Berserikat bagi Pekerja, Mandar Maju, Bandung

Bungasan Hutapea, 2010, Perlindungan Hukum Menurut Undang-Undang Nomor 13 Tahun 2003 tentang Ketenagakerjaan Bagi Pekerja Dalam Perjanjian Outsourcing, Jurnal Penelitian Hukum APHI, DE JURE, 1410-5632 Vol.10. No. 3

Lalu Husni, 2004, Hukum Ketenagakerjaan Indonesia, PT. Raja Grafindo Persada, Jakarta

Libertus Jehani, 2008, Hak-Hak Karyawan Kontrak, Forum Sahabat, Jakarta

M. Fauzi, 2006, Aspek Hukum Penyerahan Sebagian Pelaksanaan Pekerjaan Kepada Perusahaan Lain (outsourcing), Risalah Hukum Fakultas Hukum Unmul, 021969X. Vol.2, No.2

Maimun, 2004, Hukum Ketenagakerjaan Suatu Pengantar, PT.Pradnya Pramita, Jakarta

Much Nurahcmad, 2009, Tanya Jawab Seputar Hak-Hak Tenaga Kerja Kontrak (Outsourcing), Visimedia, Jakarta

N.L.M. Mahendrawati, 2009, Perjanjian Outsourcing Dalam Kegiatan Bisnis, Kertha Wicaksana, Vol.15. No 2

Redaksi RAS, 2010, Hak Dan Kewajiban Karyawan, Raih Asa Sukses, Jakarta

\footnotetext{
${ }^{36}$ Lalu Husni, Op.Cit. Hal 194.
} 